\title{
Development of Teaching Materials in Writing Text Report of Project Based Observations (Problem Based Learning) for Class X SMK Telkom 2 Medan
}

\author{
Eva Damayanti Damanik ${ }^{1}$, Khairil Ansari ${ }^{2}$, Malan Lubis ${ }^{3}$ \\ ${ }_{1,2,3}$ Universitas Negeri Medan, Indonesia \\ evadamanik90@gmail.com
}

\begin{abstract}
This study aims to determine the results of the development of teaching materials to write project-based observation report text for class $X$ SMK Telkom 2 Medan. The subjects of this study were students of class X SMK Telkom 2 Medan who were taken as many as 1 class / study group with a total of 30 students. Researchers collected information based on the results of observations of teaching materials in class $X$ SMK Telkom 2 Medan shows that the teaching materials used by teachers sofar have only used textbooks without teaching materials in the form of modules as another guide in learning, especially on the text material for the observation report. The results of the effectiveness of teaching materials for writing text c reports on the results of projectbased observations (project based learning) on a limited trial, namely 30 students of class X SMK Telkom 2 Medan, namely in the pretest test results obtained an average score of $68.97 \%$ with sufficient category . Meanwhile, after using teaching materials to write text modules on the postest test with an average score of $80.83 \%$ with a good category. These results state that the teaching materials for writing projectbased observation report text after use have a significant increase in student learning outcomes with a difference of 11.86 which indicates that by using the teaching materials to write project-based observation report text learning) student scores are better than before.
\end{abstract}

Keywords

teaching materials; folklore; sociocultural

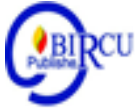

\section{Introduction}

An effort to improve the quality of education through improving the learning process is an educational innovation that continues to be implemented. One of these innovations is changing the learning paradigm from teacher-centered learning to student-centered learning. Teaching-based learning approaches are transformed into the form of learning-based learning. The main characteristic of learning-based learning is the development of students' independence to build knowledge and skills within themselves from a variety of information through an interaction in the learning process, for this purpose, of course the teacher must assist students in building their knowledge and skills by providing effective learning tools.

One of the explanations described is the provision of teaching materials because teaching materials are a determining factor for the success of the learning process, whose existence plays an important role for students and teachers. Whether or not the teaching materials are good or not is determined by the teacher's ability to select and develop teaching materials in accordance with the curriculum and student needs. As emphasized in the Minister of National Education Regulation No. 16 of 2007 regarding the standards of 
academic qualifications and teacher competence, that teachers as professional educators are expected to have the ability to develop teaching materials in accordance with existing mechanisms by paying attention to the characteristics and social environment of students. In line with the contents of the National Education System Law no.

\section{Review of Literatures}

\subsection{Teaching Materials}

Teaching materials are inseparable from the learning process in the classroom because teaching materials will facilitate the course of learning activities between teachers and students to achieve certain learning objectives. This is confirmed by Seven and Ali (2010) who state "teaching materials are very important instruments to help the leaners take part in the learning and teaching processes".

Based on the opinion of Seven and Ali, it can be interpreted that teaching materials are very important tools to help the learning and teaching process. Furthermore, Djumingin (2017: 53) states that, "teaching materials are the resources uses to deliver instruction. Each teacher requires a range of tools to draw upon in order to assist and support student learning. "It can be interpreted that teaching materials or materials are the resources used by teachers in delivering teaching. The same opinion is expressed by Sinaga (2014: 189) that teaching materials are materials consisting of various forms that are used by teachers and students to assist teachers in the process of teaching and learning activities in the classroom. Dick and Carey $(2009$; 230) add that "instructional material contains the content either written, mediated, or facilitated by an instructor that a student as use to achieve the objective also include information that the learners will use to guide the progress. "

\subsection{Definition of the Observation Report Text}

An observation report text is a type of text that provides general information about something after a systematic investigation / research is carried out. This type of text is used when teaching a topic or writing an article or research such as: objects, plants, animals, certain concepts / ecosystems. A text report usually contains facts about a matter, descriptions and information about the habits and quality of something that can be proven scientifically (Anderson through Wijanarko, 2014: 13).

Kosasih (2012: 75) says the observation report is an essay describing a phenomenon or event based on the results of observations, then explained by Harsiati (2014: 129) that the text of the observation report report is a text that functions to provide information about an object or situation after conducting systematic investigations / research.

Wahono et al, (2013:7) explain that the text of the observation result (report) is a text that presents information about something as it is. Which is the result of systematic observation and analysis which usually contains facts that can be proven scientifically which are general in nature.

\subsection{Development Methods}

The development method used in this research is research and development (R\&D) Borg \& Gall, (2003), which is a process used to develop and validate the results of an education. Research and development or R\&D methods are research methods used to produce certain products and test the effectiveness of these products (Sugiyono, 2008: 407). 


\section{Research Method}

The research on the development of teaching materials to write project-based observation report texts was carried out in class X SMK Telkom 2 Medan at the beginning of the odd semerter according to the learning schedule to write the observation report text written on the implementation plan of learning for Indonesian language teachers in class $\mathrm{X}$ SMK Telkom 2 Medan.

The subjects of this study were students of class X SMK Telkom 2 Medan who were taken as many as 1 class / study group with a total of 30 students.

The analysis of learning outcomes is seen from the cognitive realm learning outcomes derived from the minimum learning completeness (KBM). The steps used to determine the effectiveness of teaching materials are as follows;

a. Determine student learning completeness per individual which is calculated as follows

$$
\text { Score }=\frac{\text { the number of scores obtained }}{\text { total ideal score of all items }} \times 100 \%
$$

b. Classifying students' mastery of the material of writing observation report text based on the 5 scale guidelines according to Sugiyono $(2015 ; 24)$ as follows;

Table 1. Classifying Students' Mastery

\begin{tabular}{|c|c|}
\hline Criteria & Assessment score \\
\hline Very good & $85-100$ \\
\hline Well & $70-84$ \\
\hline Pretty good & $55-69$ \\
\hline Less & $40-54$ \\
\hline Very less & $0-39$ \\
\hline
\end{tabular}

Determine the average value of the LHO text writing ability using the following formula;

$$
\begin{aligned}
& \bar{x}=\frac{\sum x}{n} \\
& \text { information } \\
& \bar{x}=\text { mean (mean) } \\
& \begin{array}{l}
\sum \mathrm{x}=\text { total score multiplied by frequency } \\
\mathrm{n} \quad=\text { number of subjects }
\end{array}
\end{aligned}
$$

d. Analyze the collected data using a scale 5 analysis convention such as tables 


\section{Discussion}

Researchers collected information based on the results of observations of teaching materials in class $\mathrm{X}$ SMK Telkom 2 Medan shows that the teaching materials used by teachers so far have only used textbooks without teaching materials in the form of modules as another guide in learning, especially on the text material for the observation report. This proves that so far learning in schools has only been fixated on textbooks without using / creating modules that can facilitate teachers in the process of teaching and learning activities. The quality of learning becomes less motivating students in learning to write text reports on observation results, especially project-based. Besides the level of student creativity,

The researcher also distributed a questionnaire to 2 Indonesian language teachers and 30 students of class X SMk Telkom 2 Medan to get information about the initial needs of the writing text module for the observation report. The results of the needs questionnaire analysis conducted by researchers can be seen in table 2 .

Table 2. Student Needs Analys is Data

\begin{tabular}{|c|c|c|c|c|c|}
\hline \multirow{2}{*}{ No. } & \multirow{2}{*}{ Question } & \multirow{2}{*}{ Answer } & \multicolumn{2}{|c|}{ Frequency } & \multirow{2}{*}{ Percentage } \\
\hline & & & \begin{tabular}{|l} 
Students \\
\end{tabular} & amount & \\
\hline \multirow{2}{*}{1} & \multirow{2}{*}{$\begin{array}{l}\text { The teaching materials used } \\
\text { by the teacher in learning } \\
\text { observation report text are of } \\
\text { interest to you }\end{array}$} & Not & 27 & 27 & $90 \%$ \\
\hline & & Yes & 3 & 3 & $10 \%$ \\
\hline \multirow{2}{*}{2} & \multirow{2}{*}{$\begin{array}{l}\text { Teaching materials that have } \\
\text { been used by the teacher can } \\
\text { help you understand the } \\
\text { learning of the observation } \\
\text { result report text well }\end{array}$} & Not & 27 & 27 & $90 \%$ \\
\hline & & Yes & 3 & 3 & $10 \%$ \\
\hline \multirow[t]{2}{*}{3} & \multirow{2}{*}{$\begin{array}{l}\text { Are you familiar with project- } \\
\text { based observation report text } \\
\text { learning products }\end{array}$} & Not & 30 & 30 & $100 \%$ \\
\hline & & Yes & - & - & - \\
\hline \multirow[b]{2}{*}{4} & \multirow{2}{*}{$\begin{array}{l}\text { Do you use a project based } \\
\text { observation report text } \\
\text { learning module }\end{array}$} & Not & 30 & 30 & $100 \%$ \\
\hline & & Yes & - & - & - \\
\hline \multirow[t]{2}{*}{5} & \multirow{2}{*}{$\begin{array}{l}\text { Do you need a project based } \\
\text { observation report text } \\
\text { learning module }\end{array}$} & Not & - & - & - \\
\hline & & Yes & 30 & 30 & $100 \%$ \\
\hline
\end{tabular}


The results of the teacher needs questionnaire analysis conducted by researchers can be seen in the following table.

Table 3. Teacher Needs Analysis Data

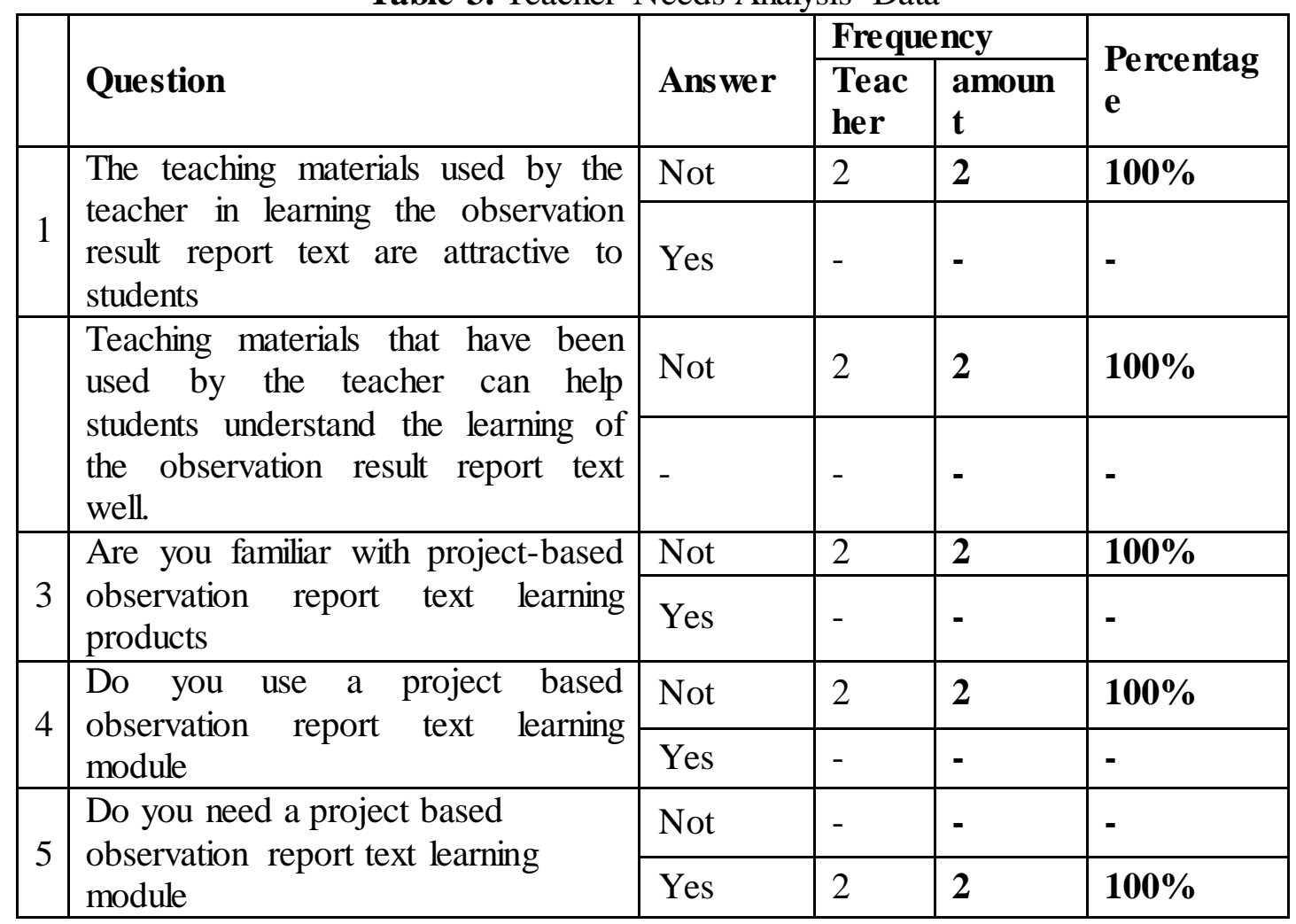

Based on the results of the needs analysis, the researcher designed a teaching material in the form of a project education-based module which was the need of students in class $\mathrm{X}$ SMK Telkom 2 Medan. The design of making teaching materials in the form of modules is carried out based on the analysis of problems that have been previously found. Module design is done by mapping the Core Competencies (KI), basic competencies (KD), and indicators. The results of the mapping obtained material that will be developed in the writing module of project-based observation reports. The module that has been compiled is then validated and declared feasible by a team of experts (validators), this product was tested in small groups and limited groups. Therefore,

Core competencies and basic competencies, and the indicators selected in the development of this product, namely:

\subsection{Core Competencies}

KI 1 Appreciate and live up to the teachings of his religion

KI 2 Respect and live out honest, disciplined, polite, confident, caring and responsible behavior in interacting effectively in accordance with the development of children in the environment, family, school, community and natural environment, nation, country and regional area.

KI 3 Understand and apply factual, conceptual, procedural, and metacognitive knowledge at a simple technical and specific level based on his curiosity about science, technology, art, culture with insight into humanity, nationality, and statehood related to visible phenomena and events. 
KI 4 Demonstrate the skills of reasoning, processing, and presenting creatively, productively, critically, independently, collaboratively, and communicatively, in the realm of the concrete and the abstract realm as learned in school and other sources of the same theory from a theoretical point of view.

\subsection{Basic Competence (KD) and Indicators}

Table 4. Mapping of KD and Indicators

\begin{tabular}{|l|l|}
\hline Knowledge Base Competencies & Indicator \\
\hline $\begin{array}{l}\text { 3.1 Understanding the results of } \\
\text { observations related to the field of work } \\
\text { presented orally and in writing }\end{array}$ & $\begin{array}{l}3.1 .1 \quad \text { Explain the meaning of the report } \\
3.1 .2 \quad \text { Suggests the types of reports } \\
3.1 .3 \quad \text { Explain the meaning of an } \\
\text { observation report } \\
3.1 .4 \text { Describe the characteristics and } \\
\text { purpose of the observation report text }\end{array}$ \\
\hline $\begin{array}{l}\text { 4.1 Presenting the contents of the text } \\
\text { (the essence) of the observation report } \\
\text { related to the field of work based on } \\
\text { interpretations both orally and in writing }\end{array}$ & $\begin{array}{l}3.1 .1 \text { Interpret the observation report. } \\
\text { observation report text. }\end{array}$ \\
\hline
\end{tabular}

Table 5. Mapping of KD and Indicators

\begin{tabular}{|l|l|l|}
\hline Knowledge Base Competencies & \multicolumn{1}{|c|}{ Indicator } \\
\hline $\begin{array}{l}\text { 3.2 Analyzing the structure and linguistic } \\
\text { aspects of a minimum of two observation } \\
\text { report texts relating to both oral and } \\
\text { written work fields }\end{array}$ & $\begin{array}{l}3.2 .1 \text { identify the structure of the } \\
\text { observation report text } \\
3.2 .2 \text { identify rulesobservation report } \\
\text { text }\end{array}$ \\
\hline $\begin{array}{l}\text { Constructing the text of the } \\
\text { observation report related to the field of } \\
\text { work by paying attention to the content } \\
\text { and aspects of language both oral and } \\
\text { written }\end{array}$ & $\begin{array}{l}4.2 .1 \text { Specifies the text theme } \\
\text { report by paying attention to the content, } \\
\text { structure and rules of the language of the } \\
\text { text } \\
4.2 .3 \text { Edit the text of the observation } \\
\text { report by paying attention to the content, } \\
\text { structure and language rules of the } \\
\text { observation report text. }\end{array}$ \\
\hline
\end{tabular}


Table 6. Grid for Teacher Responses / Responses to the Writing Module Text on Project Based Observation Results (Project Based Learning)

\begin{tabular}{|c|c|c|c|c|c|}
\hline \multirow[b]{2}{*}{ No } & \multirow[b]{2}{*}{ Indicator } & \multicolumn{4}{|c|}{ Score } \\
\hline & & 1 & 2 & 3 & 4 \\
\hline 1 & The overall appearance of the module is attractive & & & & \\
\hline 2 & Guidelines for using the module are clearly conveyed & & & & \\
\hline 3 & The language used in the module can be understood & & & & \\
\hline 4 & The presentation in the material is arranged automatically & & & & \\
\hline 5 & $\begin{array}{l}\text { The material in the module is in accordance with the } \\
\text { learning objectives }\end{array}$ & & & & \\
\hline 6 & The use of images in the module is clear & & & & \\
\hline 7 & Learning activities stimulate critical thinking skills & & & & \\
\hline 8 & The types of activities in the modules vary & & & & \\
\hline 9 & $\begin{array}{l}\text { The language used in the module is easy to understand } \\
\text { and in accordance with the level of maturity of students. }\end{array}$ & & & & \\
\hline 10 & Use of symbols in accordance with existing uses & & & & \\
\hline 11 & $\begin{array}{l}\text { Mpdul helps students understand the text material of the } \\
\text { observation report }\end{array}$ & & & & \\
\hline 12 & Modules are different from the usual teaching materials & & & & \\
\hline 13 & Modules can be studied independently by students & & & & \\
\hline 14 & The module trains students to enrich student knowledge & & & & \\
\hline 15 & $\begin{array}{l}\text { The module makes it easy for teachers to evaluate } \\
\text { students }\end{array}$ & & & & \\
\hline 16 & $\begin{array}{l}\text { The module makes it easier for students to express their } \\
\text { opinions in oral and written form }\end{array}$ & & & & \\
\hline 17 & $\begin{array}{l}\text { The module makes it easier for students to conclude the } \\
\text { material in writing the text of the observation report }\end{array}$ & & & & \\
\hline
\end{tabular}

The first step is to design a module to write a text report on project-based observation results (project based learning). The module structure developed in this study includes; covers, instructions for use, learning activities, materials, summaries, evaluation sheets.

\subsection{Product Identity}

Physical Materials

Title

Theory

Target

Author Name
: Printing Materials (printed material)

: Writing Module Text Based Observa Results

Project (Project Based Learning).

: Writing Observation Result Report Text

: Class X Student of SMK Telkom 2 Medan

: Eva Damayanti Damanik 


\subsection{Book Cover}

The process of developing teaching materials includes activities to find relevant library sources and research results as well as conducting literary studies (Tanwin, 2020). Explains. The providing of examples from both students and the teacher was a key factor for those interested in bringing creative writing into their EFL or ESL courses in order to make the function of creative writing open and understandable to those students under the instruction of the study. And if a teacher decides to incorporate creative writing, he or she should be able to compose and open to sharing the creative work that follows with students (Cogherty in Sari, 2020). The cover of the book with text material writing the text of the Observation Report has a front. Here's the explanation:

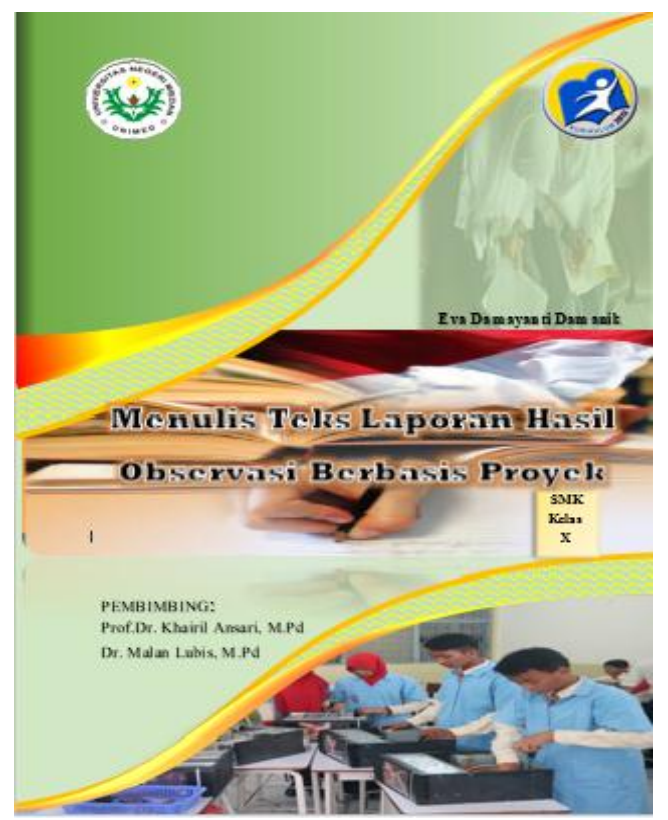

Figure 1. Cover Module Writing Project-Based Observation Report Text (Project Based Learning)

The front cover of the module consists of, the module title is adjusted to the material developed, the background is adjusted to the material in the book, it can be seen that a picture of vocational students carrying out an activity related to their assignment is intended so that readers are able to know the meaning of the title and illustration before open the contents of the module. In addition, the module is also accompanied by the author's name.

\subsection{Prakat}

The foreword is placed on the first page of the book to open the author's communication with the reader. The content of the foreword is the author's attempt to communicate with the reader, namely; 1) give thanks to God Almighty, 2) provide an explanation of the teaching material in the form of a module for writing project-based observation reports (project based learning), 3) thank you for those who have helped in compiling the short story writing module based on character education, 4) The author's expectations relating to the prospects for education and the perfection of the developed modules. 


\subsection{Learning Activities}

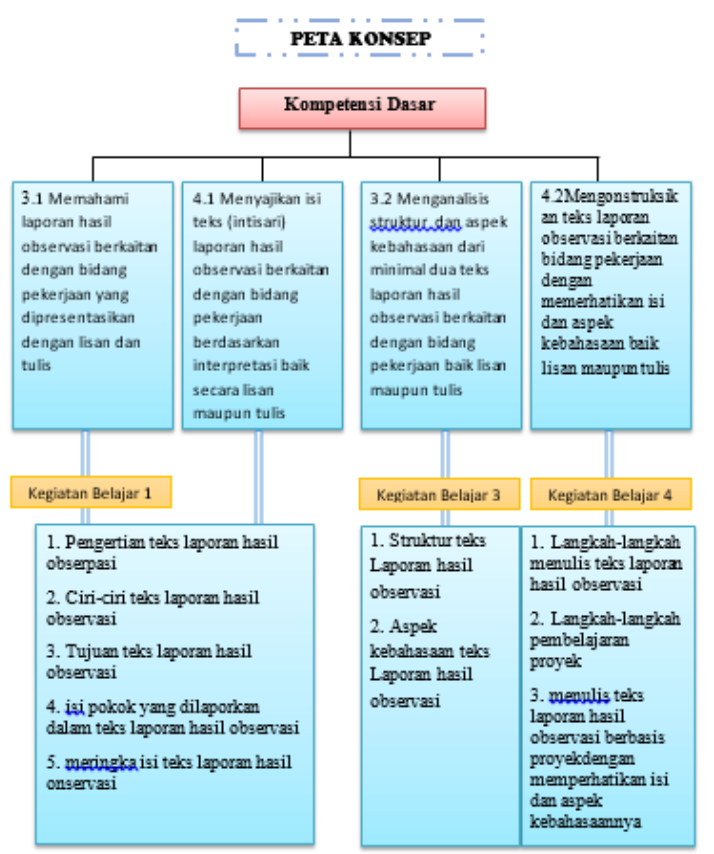

Figure 2. Learning Activities

Learning material contains material that has been determined in accordance with KI, $\mathrm{KD}$, indicators, and learning objectives in the hope that teachers and students can find out the results obtained.

\subsection{References}

Bibliography with references to reading material that is relevant to the text material of the observation report in the module.

Validation is an important part of developing teaching materials in the form of modules to correct errors and weaknesses from the design results. Validation is done by submitting a module to write a text report on the results of project-based observations (project based learning) to the validator along with the validation sheet to be checked and assessed for its feasibility level by the validator The following will describe the results of the validation and revisions made to the module in writing the text of the observation report developed.

Table 7. Content / Material Feasibility Validation Results in the Writing Text Module Project Based Observation results report (Project Based Learning)

\begin{tabular}{|l|l|l|l|l|l|l|}
\hline \multicolumn{8}{|c|}{ Content eligibility } \\
\hline Indikaor & $\begin{array}{c}\text { Respon } \\
\text { dents }\end{array}$ & $\begin{array}{c}\text { Total } \\
\text { Score }\end{array}$ & $\begin{array}{c}\text { Percenta } \\
\text { ge } \\
\text { Average }\end{array}$ & $\begin{array}{c}\text { Categor } \\
\mathbf{y}\end{array}$ \\
\hline & $\mathbf{1}$ & $\mathbf{2}$ & & & $\mathbf{8 7 . 7}$ & $\begin{array}{l}\text { Very } \\
\text { good }\end{array}$ \\
\hline Suitability of material with SK and KD & 14 & 100 & $\begin{array}{c}\text { Very } \\
\text { good }\end{array}$ \\
\hline $\begin{array}{l}\text { 1. Completeness of the material } \\
\text { (structure and language rules) }\end{array}$ & 3 & 4 & 8 & 100 & Very \\
\hline 2. The flexibility of the LHO text & 4 & 3 & 7 & 87.5 & \\
\hline
\end{tabular}




\begin{tabular}{|c|c|c|c|c|c|}
\hline material & & & & & good \\
\hline \multicolumn{3}{|l|}{ Material accuracy } & 49 & 87.5 & \\
\hline $\begin{array}{l}\text { 3. The accuracy of the concept and } \\
\text { definition of the LHO text }\end{array}$ & 3 & 4 & 7 & 87.5 & $\begin{array}{l}\text { Very } \\
\text { good }\end{array}$ \\
\hline 4. Conformity of facts and data & 4 & 3 & 7 & 87.5 & $\begin{array}{l}\text { Very } \\
\text { good }\end{array}$ \\
\hline 5. Sample text suitability & 3 & 4 & 7 & 87.5 & $\begin{array}{l}\text { Very } \\
\text { good }\end{array}$ \\
\hline $\begin{array}{l}\text { 6. Compatibility of images, } \\
\text { diagrams and objects }\end{array}$ & 3 & 4 & 7 & 87.5 & $\begin{array}{l}\text { Very } \\
\text { good }\end{array}$ \\
\hline 7. Accuracy of terms & 3 & 3 & 6 & 75 & Well \\
\hline $\begin{array}{l}\text { 8. Accuracy of notations, symbols } \\
\text { and icons }\end{array}$ & 3 & 4 & 7 & 87.5 & $\begin{array}{l}\text { Very } \\
\text { good }\end{array}$ \\
\hline 9. Reference accuracy & 4 & 4 & 8 & 100 & $\begin{array}{l}\text { Very } \\
\text { good }\end{array}$ \\
\hline \multicolumn{3}{|l|}{ Material finesse } & 36 & 92.5 & $\begin{array}{l}\text { Very } \\
\text { good }\end{array}$ \\
\hline $\begin{array}{l}\text { 10. Suitability of the material with } \\
\text { the development of science }\end{array}$ & 4 & 3 & 7 & 87.5 & $\begin{array}{l}\text { Very } \\
\text { good }\end{array}$ \\
\hline 11. Displays material topics & 4 & 4 & 8 & 100 & $\begin{array}{l}\text { Very } \\
\text { good }\end{array}$ \\
\hline $\begin{array}{l}\text { 12. Pictures, diagrams and objects } \\
\text { under study }\end{array}$ & 3 & 3 & 6 & 75 & Well \\
\hline $\begin{array}{l}\text { 13. Using examples can be found in } \\
\text { everyday life }\end{array}$ & 4 & 3 & 7 & 87.5 & $\begin{array}{l}\text { Very } \\
\text { good }\end{array}$ \\
\hline 14. Up-to-date literature & 4 & 4 & 8 & 100 & $\begin{array}{l}\text { Very } \\
\text { good }\end{array}$ \\
\hline \multicolumn{3}{|l|}{ Encourage curiosity } & 15 & 93.75 & $\begin{array}{l}\text { Very } \\
\text { good }\end{array}$ \\
\hline 15. Encourage curiosity & 4 & 4 & 8 & 100 & $\begin{array}{l}\text { Very } \\
\text { good }\end{array}$ \\
\hline 16. Creating critical thinking & 3 & 4 & 7 & 87.5 & $\begin{array}{l}\text { Very } \\
\text { good }\end{array}$ \\
\hline amount & & & & 114 & $\begin{array}{l}\text { Very } \\
\text { good }\end{array}$ \\
\hline Validation Results & 89.06 & & & Very & \\
\hline
\end{tabular}

The results of the assessment in the text writing module of the project-based observation report (project based learning) for class X students of SMK Telkom 2 Medan submitted through a questionnaire method with a questionnaire instrument presented descriptively.

Based on the results of validation by material experts on the appropriateness of the module content in writing the developed project-based learning observation report text, the percentage score was $89.06 \%$. The percentage is obtained from the calculation:

$$
\text { Percentage }=\frac{114}{16 \times 8} \times 100 \%=89,06 \%
$$


The percentage score of the feasibility of the content of the assessment instrument by material experts is very good in accordance with the validity category of the product adapted from Sugiyono (2015), so that the content contained in the writing module of the report on project-based observation reports (project based learning) being developed is not necessary revised. Feasibility of the content is suitable for use as a learning module to write projectbased observation report text (project based learning) in class X SMK Telkom 2 Medan

Table 8. Results of Presentation Feasibility Validation in the Writing Module Text on Project Based Observation Results (Project Based Learning)

\begin{tabular}{|c|c|c|c|c|c|}
\hline \multicolumn{6}{|c|}{ Serving eligibility } \\
\hline \multirow[t]{2}{*}{ Indicator } & \multicolumn{2}{|c|}{\begin{tabular}{|l|} 
Responden \\
ts \\
\end{tabular}} & \multirow[t]{2}{*}{$\begin{array}{l}\text { Total } \\
\text { Score }\end{array}$} & \multirow[t]{2}{*}{$\begin{array}{l}\text { Percentage } \\
\text { Average }\end{array}$} & \multirow[t]{2}{*}{ Category } \\
\hline & 1 & 2 & & & \\
\hline \multicolumn{3}{|l|}{ Presentation technique } & 14 & 87.5 & Very good \\
\hline $\begin{array}{l}\text { 1. Systematic consistency of } \\
\text { presentation in learning activities }\end{array}$ & 3 & 4 & 7 & 87.5 & Very good \\
\hline 2. Concept sequence & 4 & 3 & 7 & 87.5 & Very good \\
\hline \multicolumn{3}{|l|}{ Presentation of learning } & 22 & 91.66 & Very good \\
\hline 3. The involvement of students & 4 & 4 & 8 & 100 & Very good \\
\hline 4. Learner centered & 3 & 4 & 8 & 100 & Very good \\
\hline $\begin{array}{l}\text { 5. Stimulate the ability of students to } \\
\text { solve problems }\end{array}$ & 4 & 3 & 7 & 87.5 & Very good \\
\hline \multicolumn{3}{|l|}{ Completeness of the presentation } & 58 & 90.62 & Very good \\
\hline $\begin{array}{l}\text { 6. Examples of questions in each } \\
\text { learning activity }\end{array}$ & 4 & 3 & 7 & 87.5 & Very good \\
\hline $\begin{array}{l}\text { 7. Exercise questions at the end of } \\
\text { each learning activity }\end{array}$ & 3 & 4 & 7 & 87.5 & Very good \\
\hline 8. Key answers to practice questions & 3 & 3 & 6 & 75 & Well \\
\hline 9. Preliminary & 4 & 4 & 8 & 100 & Very good \\
\hline 10. Table of contents & 4 & 4 & 8 & 100 & Very good \\
\hline 11. Glossary & 4 & 3 & 7 & 87.5 & Very good \\
\hline 12. References & 4 & 4 & 8 & 100 & Very good \\
\hline 13. Summary & 3 & 4 & 7 & 87.5 & Very good \\
\hline amount & & & \multicolumn{3}{|c|}{94} \\
\hline Validation Results & \multicolumn{2}{|c|}{90.38} & & Very go & \\
\hline
\end{tabular}

Based on the results of validation by material experts on the feasibility of presenting a module in writing a project-based learning observation report text developed, it was obtained a score of $90.38 \%$. The percentage is obtained from the calculation:

$$
\text { Percentage }=\frac{94}{13 \times 8} \times 100 \%=90,38 \%
$$


Table 9. Results of Validation of Language Feasibility in the Writing Module Text on Project Based Observation Results (Project Based Learning)

\begin{tabular}{|c|c|c|c|c|c|}
\hline \multicolumn{6}{|c|}{$\begin{array}{lc}\text { Language Eligibility } \\
\end{array}$} \\
\hline \multirow[t]{2}{*}{ Indicator } & \multicolumn{2}{|c|}{$\begin{array}{l}\text { Responden } \\
\text { ts }\end{array}$} & \multirow[t]{2}{*}{$\begin{array}{l}\text { Total } \\
\text { Score }\end{array}$} & \multirow{2}{*}{$\begin{array}{l}\text { Percen } \\
\text { tage } \\
\text { Averag } \\
\text { e }\end{array}$} & \multirow[t]{2}{*}{$\begin{array}{l}\text { Categor } \\
\mathbf{y}\end{array}$} \\
\hline & $\mathbf{1}$ & 2 & & & \\
\hline \multicolumn{3}{|l|}{ Straightforward } & 21 & 87.5 & Very \\
\hline $\begin{array}{l}1 . \quad \text { The accuracy of } \text { sentence } \\
\text { structure }\end{array}$ & 4 & 4 & 8 & 100 & $\begin{array}{l}\text { Very } \\
\text { good }\end{array}$ \\
\hline 2. $\quad$ Sentence effectiveness & 3 & 4 & 7 & 87.5 & $\begin{array}{l}\text { Very } \\
\text { good }\end{array}$ \\
\hline Rigor of the term & 3 & 3 & 6 & 75 & Well \\
\hline \multicolumn{3}{|l|}{ Legibility } & 14 & 87.7 & $\begin{array}{l}\text { Very } \\
\text { good }\end{array}$ \\
\hline Message readability & 3 & 4 & 7 & 87.5 & $\begin{array}{l}\text { Very } \\
\text { good }\end{array}$ \\
\hline $\begin{array}{l}\text { 5. The accuracy of using the } \\
\text { language }\end{array}$ & 4 & 3 & 7 & 87.5 & $\begin{array}{l}\text { Very } \\
\text { good }\end{array}$ \\
\hline \multicolumn{3}{|l|}{ Dialogical and interactive } & 14 & 87.5 & $\begin{array}{l}\text { Very } \\
\text { good }\end{array}$ \\
\hline $\begin{array}{l}\text { T. The ability to motivate } \\
\text { messages or information }\end{array}$ & 3 & 4 & 7 & 87.5 & $\begin{array}{l}\text { Very } \\
\text { good }\end{array}$ \\
\hline $\begin{array}{l}\text { 7. Ability to encourage students } \\
\text { to think critically }\end{array}$ & 4 & 3 & 7 & 87.5 & $\begin{array}{l}\text { Very } \\
\text { good }\end{array}$ \\
\hline \multicolumn{3}{|c|}{$\begin{array}{l}\text { The suitability of the level of development of } \\
\text { students }\end{array}$} & 14 & 87.5 & $\begin{array}{l}\text { Very } \\
\text { good }\end{array}$ \\
\hline $\begin{array}{l}\text { 8. The suitability of students' } \\
\text { intellectual development }\end{array}$ & 4 & 4 & 8 & 100 & $\begin{array}{l}\text { Very } \\
\text { good }\end{array}$ \\
\hline $\begin{array}{l}\text { 9. Conformity with the level of } \\
\text { emotional development of students }\end{array}$ & 3 & 3 & 6 & 75 & Well \\
\hline \multicolumn{3}{|l|}{ Integration of thought lines } & 15 & 93.75 & $\begin{array}{l}\text { Very } \\
\text { good }\end{array}$ \\
\hline $\begin{array}{lll}10 . \quad \text { Integrity } & \text { between learning } \\
\text { activities } & & \\
\end{array}$ & 3 & 4 & 7 & 87.5 & $\begin{array}{l}\text { Very } \\
\text { good }\end{array}$ \\
\hline $\begin{array}{ll}11 . \quad \text { Cohesiveness } & \text { between } \\
\text { paragraphs } & \\
\end{array}$ & 4 & 4 & 8 & 100 & $\begin{array}{l}\text { Very } \\
\text { good }\end{array}$ \\
\hline \multicolumn{3}{|l|}{ Use of terms, symbols and icons } & 14 & 87.5 & $\begin{array}{l}\text { Very } \\
\text { good }\end{array}$ \\
\hline 12. Consistent use of terms & 3 & 4 & 7 & 87.5 & $\begin{array}{l}\text { Very } \\
\text { good }\end{array}$ \\
\hline 13. Consistent use of symbols & 4 & 3 & 7 & 87.5 & $\begin{array}{l}\text { Very } \\
\text { good }\end{array}$ \\
\hline amount & & & \multicolumn{2}{|l|}{92} & \\
\hline Amount average & \multicolumn{2}{|c|}{$88.46 \%$} & \multicolumn{3}{|c|}{ Very good } \\
\hline
\end{tabular}


In line with Muslich's (2011: 130) opinion the assessment criteria must be clearly stated, concise, observable, state behavior, and written in language that is easy to understand. So, based on the results of the validation by material experts on the feasibility of the module language in writing the developed project-based learning observation report text, it was obtained a score of $88.46 \%$. The percentage is obtained from the calculation:

$$
\text { Percentage }=\frac{92}{13 \times 8} \times 100 \%=88,46 \%
$$

In addition to grading, the validator also provides input in the form of comments and suggestions related to the aspects being assessed in the module of writing project-based observation report text. As for the explanation of things that need to be revised or comments on the character education-based short story writing module provided by material experts, namely, there are several texts and at the emotional sub-level of students that need to be improved. All comments and suggestions given by the validator will be taken into consideration in making revisions to the module in writing the project-based learning result report text that was developed.

Table 10. Aspect Validation Results Writing Project-Based Observation Report Text (Project Based Learning) in the Module

\begin{tabular}{|c|c|c|c|c|c|}
\hline \multicolumn{6}{|c|}{ Project Based Learning Aspects } \\
\hline \multirow[t]{2}{*}{ Indicator } & \multicolumn{2}{|c|}{$\begin{array}{c}\text { Responden } \\
\text { ts }\end{array}$} & \multirow[t]{2}{*}{$\begin{array}{l}\text { Total } \\
\text { Score }\end{array}$} & \multirow{2}{*}{$\begin{array}{l}\text { Percentage } \\
\text { Average }\end{array}$} & \multirow[t]{2}{*}{$\overline{\text { Category }}$} \\
\hline & 1 & 2 & & & \\
\hline \multicolumn{3}{|l|}{ Motivate students } & 15 & 93.75 & Very \\
\hline 1. Find new ideas & 3 & 4 & 7 & 87.5 & $\begin{array}{l}\text { Very } \\
\text { good }\end{array}$ \\
\hline 2. Motivate & 4 & 4 & 8 & 100 & $\begin{array}{l}\text { Very } \\
\text { good }\end{array}$ \\
\hline \multicolumn{3}{|l|}{ Work in groups } & 14 & 87.5 & $\begin{array}{l}\text { Very } \\
\text { good }\end{array}$ \\
\hline 3. Cooperate & 4 & 3 & 7 & 87.5 & $\begin{array}{l}\text { Very } \\
\text { good }\end{array}$ \\
\hline 4. Give an opinion & 3 & 4 & 7 & 87.5 & $\begin{array}{l}\text { Very } \\
\text { good }\end{array}$ \\
\hline \multicolumn{3}{|l|}{ Solving problems } & 13 & 81.25 & $\begin{array}{l}\text { Very } \\
\text { good }\end{array}$ \\
\hline 5. Skilled in solving problems & 3 & 4 & 7 & 87.5 & $\begin{array}{l}\text { Very } \\
\text { good }\end{array}$ \\
\hline 6. Interesting & 3 & 3 & 6 & 75 & Well \\
\hline amount & 20 & 22 & \multicolumn{3}{|c|}{42} \\
\hline Amount average & \multicolumn{2}{|c|}{87.5} & \multicolumn{3}{|c|}{ Very good } \\
\hline
\end{tabular}

Based on the results of validation by material experts on the module aspects of writing project-based learning reports that were developed, the percentage score was $87.5 \%$. (Very good) The percentage is obtained from the calculation: 


$$
\text { Percentage }=\frac{42}{6 \times 8} \times 100 \%=87,5 \%
$$

Product design validation was carried out by Dr. Tappil Rambe, S.Pd, M. Si and Dr. Evi Eviyanti, M.Pd who is a Lecturer at Medan State University. The assessment was carried out to obtain information on the quality of the module in writing project-based observation report text (project based learning) which was developed to improve the quality of learning at SMK Telkom 2 Medan on the material of writing observation report text.

Table 11. Design Validation Results on the Aspects of Graphic Feasibility in the Writing Module Project-based Observation Report Text (Project Based Learning)

\begin{tabular}{|c|c|c|c|c|c|}
\hline \multicolumn{6}{|c|}{ Appropriateness } \\
\hline \multirow[t]{2}{*}{ Indicator } & \multicolumn{2}{|c|}{$\begin{array}{l}\text { Responden } \\
\text { ts }\end{array}$} & \multirow[t]{2}{*}{$\begin{array}{l}\text { Total } \\
\text { Score }\end{array}$} & \multirow[t]{2}{*}{$\begin{array}{l}\text { Percentage } \\
\text { Average }\end{array}$} & \multirow[t]{2}{*}{ Category } \\
\hline & 1 & 2 & & & \\
\hline Module Size & & & 14 & 87.5 & Very good \\
\hline $\begin{array}{l}\text { 1. conformance to ISO standards (A4, } \\
\text { A5 and B5) }\end{array}$ & 3 & 4 & 7 & 87.5 & Very good \\
\hline 2. suitability of size to the material & 4 & 3 & 7 & 87.5 & Very good \\
\hline Cover design & & & 63 & 87.5 & Very good \\
\hline $\begin{array}{l}\text { 3. The appearance of the layout elements } \\
\text { on the front, back and back covers } \\
\text { harmoniously has rhythm and unity } \\
\text { and is consistent. }\end{array}$ & 3 & 4 & 7 & 87.5 & Very good \\
\hline 4. Showing a good center point. & 3 & 3 & 6 & 75 & Well \\
\hline $\begin{array}{l}\text { 5. The color of the layout elements is } \\
\text { harmonious and clarifies the function. }\end{array}$ & 3 & 4 & 7 & 87.5 & Very good \\
\hline $\begin{array}{l}\text { 6. The composition and size of the layout } \\
\text { elements (title, author, illustration, logo, } \\
\text { etc.) are proportional, balanced, and in } \\
\text { tune with the content layout (according to } \\
\text { the pattern). }\end{array}$ & 4 & 3 & 7 & 87.5 & Very good \\
\hline $\begin{array}{l}\text { 7. The font size used is attractive and } \\
\text { easy to read. }\end{array}$ & 3 & 4 & 7 & 87.5 & Very good \\
\hline $\begin{array}{l}\text { 8. The color of the title of the teaching } \\
\text { material contrasts with the color of the } \\
\text { background. }\end{array}$ & 3 & 4 & 7 & 87.5 & Very good \\
\hline $\begin{array}{l}\text { 9. Do not use too many font } \\
\text { combinations. }\end{array}$ & 4 & 4 & 8 & 100 & Very good \\
\hline 10. Cover Illustration & 4 & 3 & 7 & 87.5 & Very good \\
\hline $\begin{array}{l}\text { 11. Describe the content / teaching material } \\
\text { and reveal the character of the object. }\end{array}$ & 3 & 4 & 7 & 87.5 & Very good \\
\hline Content Design & & & 140 & 87.5 & Very good \\
\hline $\begin{array}{l}\text { 1. The placement of layout elements is } \\
\text { consistent based on the pattern }\end{array}$ & 4 & 4 & 8 & 100 & Very good \\
\hline 2. The separation between paragraphs is & 4 & 4 & 8 & 100 & Very good \\
\hline
\end{tabular}




\begin{tabular}{|c|c|c|c|c|c|}
\hline clear & & & & & \\
\hline $\begin{array}{l}\text { 3. Proportional printable } \\
\text { margins }\end{array}$ & 3 & 4 & 7 & 87.5 & Very good \\
\hline $\begin{array}{llll}\text { 4. } & \text { Adjoining page margins } \\
\text { proportional }\end{array}$ & 4 & 3 & 7 & 87.5 & Very good \\
\hline $\begin{array}{l}\text { 5. The spaces between the text and the } \\
\text { illustrations are appropriate }\end{array}$ & 3 & 4 & 8 & 100 & Very good \\
\hline $\begin{array}{l}\text { 6. Placement of learning activity titles, } \\
\text { learning activity subtitles, and page / } \\
\text { folio numbers is correct }\end{array}$ & 4 & 4 & 8 & 100 & Very good \\
\hline $\begin{array}{l}\text { 7. The placement of illustrations and } \\
\text { captions is correct }\end{array}$ & 3 & 3 & 6 & 6 & Well \\
\hline $\begin{array}{l}\text { 8. Placement of decoration / illustration } \\
\text { as background does not interfere with } \\
\text { title, text, page numbers }\end{array}$ & 4 & 3 & 8 & 100 & Very good \\
\hline $\begin{array}{l}\text { 9. Placement of titles, subtitles, } \\
\text { illustrations, and captions does not } \\
\text { interfere with understanding. }\end{array}$ & 3 & 4 & 8 & 100 & Very good \\
\hline 10. Don't use too many fonts & 4 & 3 & 7 & 87.5 & Very good \\
\hline $\begin{array}{l}\text { 11. The use of letter variations (bold, } \\
\text { italic, all capital, small capital) is not } \\
\text { excessive. }\end{array}$ & 4 & 3 & 8 & 100 & Very good \\
\hline 12. Normal text arrangement width. & 3 & 4 & 7 & 87.5 & Very good \\
\hline $\begin{array}{l}\text { 13. Space between lines of normal text } \\
\text { arrangement. }\end{array}$ & 3 & 4 & 7 & 87.5 & Very good \\
\hline 14. Normal kerning. & 3 & 3 & 7 & 87.5 & Very good \\
\hline $\begin{array}{l}\text { 15. The level / hierarchy of the titles is } \\
\text { clear, consistent and proportional. }\end{array}$ & 3 & 4 & 6 & 75 & Well \\
\hline 16. Hyphenation. & 3 & 4 & 7 & 87.5 & Very good \\
\hline 17. Content Illustration & 4 & 4 & 7 & 87.5 & Very good \\
\hline $\begin{array}{l}\text { 18. Be able to reveal the meaning / } \\
\text { meaning of objects. }\end{array}$ & 4 & 4 & 6 & 75 & Very good \\
\hline $\begin{array}{l}\text { 19. Accurate and proportional form } \\
\text { according to reality. }\end{array}$ & 3 & 4 & 7 & 87.5 & Very good \\
\hline 20. Creative and dynamic & 4 & 3 & 7 & 87.5 & \\
\hline & & & \multicolumn{3}{|c|}{217} \\
\hline Amount average & \multicolumn{2}{|l|}{87.5} & \multicolumn{3}{|c|}{ Very good } \\
\hline
\end{tabular}

The results of the assessment of the module design writing text report on the results of project-based observations (project based learning) in class X SMK Telkom 2 Medan submitted through a questionnaire method with a questionnaire instrument presented descriptively. Based on the results of validation by design experts on the developed project- 
based learning observation report text writing module, the score was $87.5 \%$. (Very good) The percentage is obtained from the calculation:

$$
\text { Percentage }=\frac{217}{31 \times 8} \times 100 \%=87,5 \%
$$

The percentage of the score on the assessment instrument by the design expert is very valid, so the module for writing project-based learning reports that is developed does not need to be revised.

Table 12. Assesment of Modules

\begin{tabular}{|l|l|l|c|}
\hline No. & Assessment of modules & $\begin{array}{c}\text { Average } \\
\text { percentage value }\end{array}$ & Criteria \\
\hline 1 & Teacher's Response (2 Pax) & 89.71 & Very good \\
\hline 2 & Testing on Students (30 people) & 90.63 & Very good \\
\hline
\end{tabular}

Table 13. Pretest Results before using the Writing Module Project-Based Observation Results Report Text (Project Based Learning)

\begin{tabular}{|l|l|c|}
\hline \multirow{2}{*}{ No. } & \multicolumn{1}{|c|}{ Student's Name } & Student Assessment \\
\cline { 3 - 3 } & & Pretest \\
\hline 1 & Fitra Mulia Lubis Agreement & 60 \\
\hline 2 & Arya Prasetio Wibowo & 67 \\
\hline 3 & Arzety Bilbina & 60 \\
\hline 4 & Azriel Akbar & 55 \\
\hline 5 & Build Hotdiasi Sitorus & 60 \\
\hline 6 & Rose Love Hasibuan & 70 \\
\hline 7 & Elvy Yolanda Lubis & 74 \\
\hline 8 & Filldavid Raygelliam Siahaan & 83 \\
\hline 9 & Haiqal Syafiq Harahap & 75 \\
\hline 10 & Sukron Day & 70 \\
\hline 11 & Hariaran & 75 \\
\hline 12 & Hariyono By He & 65 \\
\hline 13 & Jeremia Putra Panggabean & 76 \\
\hline 14 & Jordan Haganta Ginting Munthe & 70 \\
\hline 15 & M. Radja Syah & 75 \\
\hline 16 & Michael Gilbert Tardas Sinaga & 50 \\
\hline 17 & Michael Pedrosa Sigalingging & 75 \\
\hline 18 & Mika Athallah Keesa & 73 \\
\hline 19 & Najla Afifah Rangkuti & 70 \\
\hline 20 & Nurhadi Saputra & 80 \\
\hline 21 & Nurhalipa & 78 \\
\hline 22 & Rahmad Nawi Pane & 65 \\
\hline 23 & Rahmat Hardiansyah Siregar & 80 \\
\hline 24 & Refandi Arya Dwitama Lubis & 70 \\
\hline 25 & Risfa Hafizah & 80 \\
\hline 26 & Hisikia Simanungkalit & \\
\hline 27 & Ryan Fahrezi Daulay & 75 \\
\hline & & \\
\hline
\end{tabular}




\begin{tabular}{|c|l|c|}
\hline 28 & Ade Sahputra Purba & 72 \\
\hline 29 & Akas Rohit & 68 \\
\hline 30 & Ayumi Keisha Putri & 50 \\
\hline & Total & 2069 \\
\hline \multicolumn{2}{|c|}{ Average } & $\mathbf{6 8 . 9 7}$ \\
\hline
\end{tabular}

Table 14. Frequency Distribution of Pretest and Post-Test Values Writing Project-Based Observation Report Texts (Project Based Learning)

\begin{tabular}{|c|c|c|c|c|}
\hline \multirow{2}{*}{ Criteria } & \multicolumn{2}{|c|}{ Pretest } & \multicolumn{2}{c|}{ Postest } \\
\cline { 2 - 5 } & Frequency & Percentage & Frequency & Percentage \\
\hline $85-100$ & - & - & 12 & $40 \%$ \\
\hline $70-84$ & 19 & $63.33 \%$ & 16 & $53.33 \%$ \\
\hline $55-69$ & 8 & $26.67 \%$ & 2 & $6.67 \%$ \\
\hline $40-54$ & 3 & $10 \%$ & - & \\
\hline $0-39$ & - & - & - & $100 \%$ \\
\hline$\sum$ & 30 & $100 \%$ & 30 & \multicolumn{2}{c}{} \\
\hline
\end{tabular}

Based on table 4.16 shows that at the time of the pretest students who got a score of 70 84 were 19 students with a percentage of $63.33 \%$, the value of 55-69 was 8 students with a percentage of $26.67 \%$ and at a value of $40-54$ as many as 3 students with persentsae $10 \%$. The posttest scores experienced an increase in better learning outcomes, namely a value of $85-100$ as many as 12 students with a percentage of $40 \%$, a value of $70-84$ as many as 16 students with a percentage of $53.33 \%$, and a value of 55-69 as many as 2 students with a percentage of $6.67 \%$.

\section{Conclusion}

The process of developing teaching materials to write project-based observation report text in class X SMK Telkom 2 Medan through several stages, namely; Preliminary study, namely research and preliminary information gathering, namely needs analysis. Analysis of development needs begins by distributing a questionnaire to analyze the needs of students of class X SMK Telkom 2 as many as 30 students and 2 Indonesian language teachers. The results of the needs analysis $100 \%$ of the teachers stated that they did not know the teaching materials for writing project-based observation report text (project-based learning) and 100\% of the teachers did not use teaching materials to write project-based observation report text (project based learning), so that $100 \%$ of teachers requires teaching materials to write short story texts based on character education that are valid, effective and practical.

The process of developing teaching materials to write project-based learning report text has been completed, the next stage is designed, namely the initial product development and validated by validators, namely material experts and design experts. The feasibility of the module in the criteria is very good with an average of $89.3 \%$ based on the feasibility of content $89.0 \%, 90.38 \%$ presentation feasibility and $88.46 \%$ language feasibility then design feasibility with an average of $87.5 \%$ in the very category well. The results of the teacher's questionnaire response to the module with an average of $89.71 \%$ and student responses to the module also stated very good with an average of $90.63 \%$. based on trials, namely individual trials, small group trials and limited group trials. 
The results of the effectiveness of teaching materials for writing text c reports on the results of project-based observations (project based learning) on a limited trial, namely 30 students of class X SMK Telkom 2 Medan, namely in the pretest test results obtained an average score of $68.97 \%$ with sufficient category . Meanwhile, after using teaching materials to write text modules on the postest test with an average score of $80.83 \%$ with a good category. These results state that the teaching materials for writing project-based observation report text after use have a significant increase in student learning outcomes with a difference of 11.86 which indicates that by using the teaching materials to write project-based observation report text learning) student scores are better than before.

\section{References}

Adelita. 2015. The Effect of Invention Learning Model on Writing Text. Vol. 10. Terrain. Unimed.

Akker, J, V, D. 1999. Principles And Methods Of Development Research. In Plomp, T; Nieven, Ngustafson, K; Branch, R, M; Dan Vanden Akker, J (eds). Design Approaches

Ang Tools In Education And Training. London: Kluwer Academic Publisher

Borrd N Gall. 1983. Educational Research, An Introductional. New York And London. Longman.Inc.

Daryanto and Aris Dwicahyono. 2014. Development of Learning Tools (Syllabus, Rpp, Phb, Teaching Materials). Yogyakarta: Gava Media.

Daryanto. 2013. Developing Modules: Teaching Materials for Teacher Preparation in Teaching: Yogyakarta: Gava Media.

Daryanto. 2013. Developing Modules: Teaching materials for Teacher Preparation in Teaching. Yogyakarta: Gave Media

Dick, Walter., Lou Carey, and James O 'Carey 2009. The Systematic Desin Of Instruction. London: Pearson Education Ltd.

Djumingin, Sulastri. 2017. The Practice Of Lesson Study Model In Teaching Writing Repost Text ,. Journal Of Education And Learning, Vol. 11 No.1. P. 53.

Hamdani. 2011. Teaching and Learning Strategies. Bandung: Faithful Library

Hartono. 2011. Research Methodology. New Pecan. Zanafa Publishing.

Keraf. Gorys. 2004. Composition: An Introduction to Language Proficiency. Flores: Nusa Indah

Kosasih. E. 2012. Types of Text. Bandung: Yrama Widya

Kurniawati, Eni Dewi. 2009. Development of Indonesian Language and Literature Teaching Materials with a Thematic Approach: Study on Development of the Sambas 2 Public High School. University Thesis March 11.

Lestari, Ika. 2013. Competency-Based Teaching Materials Development. Jakarta: Index

Ministry of National Education. 2006. Learning Techniques With Modules. Jakarta: Director General of Primary and Secondary Education

Ministry of National Education. 2010. Guidelines for the Development of Teaching Materials. Jakarta: Ministry of National Education

Ministry of Education and Culture 2013. Indonesian Language Forum for Knowledge. Jakarta: State Polytechnic of Creative Media

Ministry of Education and Culture. 2015. Indonesian Class X SMA / SMK / MA. Jakarta: Center for Curriculum and Bookkeeping, Balitbang, Kemendikbud.

Muslich, Mansoor. 2011. Character Education Responds to Multidimensional Crisis Challenges. Jakarta: Earth Literacy 
Permendikbud. 2014. Guidelines for Strengthening Junior High School Learning Process. Module. Not Published.

Permendikbud. 2017. Guidelines for Strengthening Junior High School Learning Process. Module. Not Published.

Permendiknas N0.16 of 2007 concerning Academic Qualification Standards.

Prastowo. A. 2015. Creative Guide to Making Innovative Teaching Materials Creating Interesting And Fun Learning Methods. Yog yakarta: Diva Press.

Rusel D. James. 1997. Learning Technology and Media for learning.

Sani, Ridwan Abdullah. 2014. Learning Innovations. Jakarta: Earth Literacy.

Sari, W.S., Hasibuan, J.R., and Putri, C.A. (20200. Facilitating Novice Writers with Creative Writing Workshop in Poetry Writing Classroom (Indonesian EFL Context). Budapest nternational Research and Critics in Linguistics and Education (BirLE) Journal Vol 3 (2): 706-713.

Setyosari. Punaji. 2015. Research and Development Methods. Jakarta: Prenada Media Group.

Sinaga, Herti Arnita. 2014. Development of Teaching Materials to Improve the Ability to Write Texts of Junior High School Students for the 2013/2014 Academic Year. Journal of Language and Literature Education Vol.2 No. 3. Pg 100-200.

Sugiono. 2008. Understanding Qualitative Research. Bandung: Alfabeta.

Sugiono. 2015. Educational Research Methods, Quantitative, Creative, Qualitative and Rnd Approaches. Bandung: Alfabeta. National Sidiknas Law No. 20 of 2013 Article 39.

Tanwin, Rosliani. (2020). The Development of Indonesian Language Teaching Materials for Beginner Level of Foreign Speakers with Local Content Suwandy. Budapest International Research and Critics in Linguistics and Education (BirLE) Journal Vol 3 (3): 1600-1613.

Where. 2014. Curriculum Development in the Context of Implementation of Student Education Process Standards. Jakarta: PT. Rineka Cipta 